\title{
Функціональний стан серцево-судинної системи веслувальників високої кваліфікації в процесі інтенсивної змагальної діяльності
}

\author{
УДК 797.12+796.093:611.1(045) \\ О. А. Шинкарук, Л. О. Тайболіна
}

Національний університет фізичного виховання і спорту України, Київ, Україна

Резюме. Мета. Довести ефективність та практичну реалізацію методу векторкардіографії (ВКГ) для оцінки функціонального стану серцево-судинної системи веслувальників високої кваліфікації в умовах інтенсивної змагальної діяльності. Методи. Аналіз змагальної діяльності (відеоаналіз, аналіз протоколів змагань), педагогічне спостереження, метод векторкардіографії, методи математичної статистики. Для вивчення адаптаційної перебудови серцево-судинної системи спортсменів високої кваліфікації застосовувався електрофізіологічний метод дослідження кількісної просторової векторкардіографії за ортогональною системою відведень К. Хупке і Р. Венгера із застосуванням розробленого для цієї системи кількісного просторового методу аналізу. Дослідження проводилися щодня, вранці, в стані відносного спокою, відразу після сну. Контингент - члени збірної команди з веслування на каное. Результати. Доведено перевагу методу ВКГ перед ЕКГ щодо більш ранньої діагностики початкових форм гіпертрофії. ВКГ дозволяє краще виявити резервні можливості серця, стабільність її графіки при динамічних спостереженнях, розкриває перспективи використання ВКГ як інформативного методу дослідження поточного функціонального стану в різних струткурних утвореннях річного циклу. За результатами досліджень $€$ можливість проведення корекції тренувального процесу, заходів відновлювальної терапії. Відзначено, що в одному екіпажі - каное двійці - спостерігається індивідуальна адаптація серцевого м'яза на змагальні навантаження протягом п'яти днів. У першого спортсмена на другий день змагань спостерігалась тенденція до реалізації можливостей серцевого м'яза і на третій день його максимальна реалізація, реагування на змагальні навантаження правих відділів серцевого м'яза та накопичення на четвертий день змагань (після проходження пяти стартів та виходу у фінал на олімпійській дистанції С2 1000 м) втомлення та ознаки недовідновлення. У другого спортсмена в екіпажі реалізацію можливостей серцевого м'яза відзначено на третій день змагань, на змагальні навантаження переважно реагували ліві відділи серцевого м'яза. Про це свідчить і виступ спортсменів на третій день змагань у полуфіналі та потрапляння до фіналу на олімпійській дистанції 1000 м. Проходження олімпійської дистанції 1000 м від попереднього до фінального заїздів свідчить про максимальну реалізацію можливостей саме в полуфінальному заїзді, де екіпаж продемонстрував проходження дистанції без западінь з утриманням швидкості, кращий час на відрізках. Висновок. Адаптація серцевого м'яза під впливом змагальних навантажень у змагальному періоді, спрямована на розкриття та реалізацію функціональних можливостей, мала суто індивідуальні прояви. Прояви індивідуального ремоделювання, серцевого м'яза пов'язані 3 віком, кваліфікацією, спортивним стажем та інші. Застосування методу векторкардіографії дозволило здійснювати постійний моніторинг навантажень, вносити корекцію в тренувальний процес та підвести спортсменів до реалізації функціональних можливостей серцевого м'яза в дні, на які припадали полуфінальні та фінальні заїзди.

Ключові слова: векторкардіографія, функціональний стан, серцево-судинна система, индивідуалізація, моніторинг, змагання, елітні спортсмени. 


\section{Functional condition of cardiovascular system of highly skilled rowers in the process of intensive competitive activity.}

\section{O. A. Shynkaruk, L. O. Taibolina}

National University of Physical Education and Sport of Ukraine, Kyiv, Ukraine

Abstract. Objective. To prove the effectiveness and practical implementation of the vector cardiography method (VCG) for assessing the functional state of the cardiovascular system of highly skilled rowers in conditions of intensive competitive activity. Methods. Analysis of competitive activity (video analysis, analysis of competition protocols), pedagogical observation, vector cardiography method, methods of mathematical statistics. To study the adaptive restructuring of the cardiovascular system of highly qualified athletes, the electrophysiological method of studying quantitative spatial vector cardiography using the orthogonal lead system of K. Hupke and R. Wenger was applied using the quantitative spatial analysis method developed for this system. Studies were carried out daily, in the morning, in a state of relative rest, immediately after sleep. Contingent - members of the canoeing team. Results. The advantage of the vector cardiography method over the ECG in the earlier diagnosis of the initial forms of hypertrophy is proved. Vector cardiography method allows better identifying the reserve capabilities of the heart, the stability of its graphics during dynamic observations, reveals the prospects for using vector cardiography method as an informative method of studying the current functional state in various structural units of annual cycle. The findings enable to carry out the correction of the training process, measures of rehabilitation therapy.

It is noted that in one canoe-pair, individual adaptation of cardiac muscle to competitive loads is observed for 5 days. On the second day of the competition, the 1st athlete showed a tendency to realize the capabilities of the heart muscle and its maximum realization on the third day, reacting to the competitive loads of the right heart and accumulating fatigue by the $4^{\text {th }}$ day of the competition (after 5 starts and qualifying to the final at the Olympic distance C2 $1000 \mathrm{~m}$ ) and signs of underrecovery. In the $2^{\text {nd }}$ athlete, the realization of the capabilities of the heart muscle was noted on the third day of the competition, the left of the heart mainly responded to the competitive loads. This is evidenced by the performance of athletes on the $3^{\text {rd }}$ day of the competition in the semifinals and getting into the final at the Olympic distance of $1000 \mathrm{~m}$. Passing the Olympic distance of $1000 \mathrm{~m}$ from preliminary to final races indicates the maximum realization of the possibilities in the semi-final race, where the canoeists demonstrated the distance covering without retention of speed, the best time in the segments. Conclusion. Adaptation of the heart muscle under the influence of competitive loads in the competitive period, aimed at revealing and implementing functional capabilities, had purely individual manifestations. Manifestations of individual remodeling of the heart muscle are associated with age, qualification, and sports experience. Using the vector cardiography method allowed constant monitoring of loads, making corrections to the training process, and bringing athletes to the realization of heart functionality on days of semifinal and final races.

Keywords: vector cardiography, functional state, cardiovascular system, individualization, monitoring, competitions, elite sportsmen.

Постановка проблеми. Одним з актуальних питань спортивної підготовки спортсменів високої кваліфікації залишається пошук шляхів вдосконалення багаторічного процесу занять спортом та демонстрація високих спортивних результатів тривалий час $[6,27,28]$. Спостерігається виражене протиріччя між постійним підвищенням вимог до організму спортсменів високої кваліфрікації, що обумовлено тенденцією до зростання світових досягнень, необхідністю оптимізації та інтенсифікації тренувального процесу з урахуванням специффіки змагальної діяльності на різних дистанціях, та граничними можливостями людини, які надані природою, повноцінна реалізація яких багато в чому обмежена недостатньою розробленістю теоретико-методичних основ індивідуалізації спортивного тренування $[21,25,32]$.
Спортивне тренування спрямоване на формування довгострокової адаптації організму до інтенсивної м'язової діяльності, що дозволяє розвивати значні м'язові зусилля і виконувати роботу більшої інтенсивності та тривалості $[1,15,18,30$, 33].

Особливості адаптації в спорті визначаються специфікою фрізичних навантажень, спортивним стажем і кваліфікацією, віком і статтю спортсменів, умовами тренувально-змагальної діяльності $[3-5,11]$.

Стійкість фрізіологічних функцій, їх «відносна стабільність» або навіть «ультрастабільність» формують оптимальні межі гомеостазу при напруженій спортивній діяльності та, в результаті, специфічну адаптацію організму спортсмена до мінливих умов зовнішнього середовища [33]. Отже, в 
кожному виді спорту, в кожній спортивній дисципліні існують специфрічні характеристики фрізичної і фрункціональної підготовленості, які визначають досягнення вищих спортивних результатів і формуються безпосередньо в практичній тренувальній роботі, а реалізуються в спортивних змаганнях $[8,9,13]$.

Тренованість спортсмена характеризується високим рівнем розвитку функціональних можливостей різних систем і доброю пристосованістю їх до зростаючих фрізичних навантажень. Це дозволяє забезпечувати стійкі високі спортивні результати.

Фахівці відзначають, що стан серцево-судинної системи спортсмена в період виконання інтенсивних фрізичних навантажень $€$ важливим чинником, що визначає успішність і ефективність тренувальної діяльності. Втома у спортсменів супроводжується напруженням механізмів адаптації серцево-судинної системи. Це потребує постійного моніторингу стану спортсменів як в умовах тренувального процесу, так і в змагальній діяльності. У циклічних видах спорту, таких, як веслування, успішність тренувальної та змагальної діяльності спортсменів багато в чому залежить від мобілізаційних можливостей фрізіологічних систем організму. Домінуючою в цьому відношенні $\epsilon$ серцево-судинна система $[2,7,10,17$, 20, 30].

Аналіз фрізіологічних параметрів функціонування ССС використовується рядом фахівців у галузі спортивної медицини, тренерами для оцінки функціонального стану спортсмена [3, 12, 19]. Фізичні навантаження часто призводять до виникнення стомлення або перевтоми і супроводжуються розвитком змін у ССС. Це спрямовує на проведення досліджень щодо пошуку ефективних засобів та методів моніторингу функціонального стану організму спортсменів протягом багаторічного тренування, протягом річного циклу, в різних структурних утвореннях, для забезпечення оптимального функціонування організму спортсменів в умовах інтенсивної м'язової діяльності [24, 26, 30-32].

Електричні процеси в серцевому м'язі, що несуть важливу інформацію як про сам орган, так i про шляхи і ступінь його іннервації, вивчаються в основному за допомогою методів електрокардіографії (ЕКГ), векторкардіографії (ВКГ), методів математичного аналізу варіабельності серцевого ритму. Методи ВКГ та ЕКГ дозволяють оцінити наявність і ступінь вияву гіпертрофії міокарда різних відділів серця, оцінити метаболічне забезпечення м'яза серця, виявити гемодинамічне перевантаження передсердя, тобто визначити шляхи адап- тації серця до фрізичних навантажень різної спрямованості [14, 16, 19].

Розроблені критерії оцінки високих і знижених резервних можливостей серця дозволяють своєчасно вносити корекцію в тренувальний процес, сприяють його оптимізації. Метод ВКГ знайшов широке застосування як у циклічних, так і в таких видах спорту, як важка атлетика, гімнастика спортивна і гімнастика художня, стрибки у воду, веслувальний слалом, боротьба греко-римська, боротьба вільна тощо.

Особливо цікавим $є$ аналіз параметрів функціонального стану серцево-судинної системи в специфрічних умовах змагальної діяльності як системоутворюючого чинника, який в різних видах спорту дозволяє спортсмену, екіпажу чи команді продемонструвати максимальний для даного етапу (періоду) підготовки спортивний результат [23, 27-31], підґрунтям якого $€$ раціонально побудований тренувальний процес, моделювання та управління процесом підготовки, фрункціональний стан спортсменів, індивідуальні показники реакції на навантаження та відновлення спортсменів.

Мета дослідження - довести ефективність та практичну реалізацію методу ВКГ для оцінки фрункціонального стану серцево-судинної системи веслувальників високої кваліфрікації в умовах інтенсивної змагальної діяльності (головні змагання річного циклу).

Методи і організація дослідження: аналіз змагальної діяльності (відеоаналіз, аналіз протоколів змагань), педагогічне спостереження, метод векторкардіографії, методи математичної статистики.

Відеоаналіз та аналіз протоколів змагань, педагогічне спостереження проводили в динаміці в змагальному мікроциклі змагального періоду - на головних змаганнях річного циклу - ліцензійному чемпіонаті світу 2019 р. з веслування на байдарках і каное.

Для вивчення адаптаційної перебудови серцево-судинної системи спортсменів високої кваліфрікації застосовувався електрофрізіологічний метод дослідження кількісної просторової ВКГ за ортогональною системою відведень К. Хупке і Р. Венгера із застосуванням розробленого для цієї системи кількісного просторового методу аналізу. Реєструвалися показники: величина моментних векторів деполяризації шлуночків - початкового (П), головного (Г) і кінцевого (К); максимальний вектор реполяризації шлуночків (Т); загальна просторова площа шлуночкової петлі (QRS); загальна просторова площа петлі (T); загальна просторова площа петлі $(\mathrm{P})$; моментний вектор $\left(\mathrm{P}_{2}\right)$, що 
характеризує деполяризацію обох передсердь; коефіцієнт Г/К, що показує відношення біопотенціалов міокарда вільної стінки лівого шлуночка і основи серця; коефріцієнт Г/Т, що характеризує відношення процесів де- і реполяризації; коефріці$\epsilon$ т $Г / P_{2}$, що характеризує відношення біопотенціалів головного вектора деполяризації шлуночків і вектора, що характеризує деполяризацію обох передсердь [2, 14, 16, 22]. Дослідження проводилися щодня, вранці, в стані відносного спокою, відразу після сну.

Змагання проходили п'ять днів (з 21 по 25 серпня 2019 р. в Угорщині). Програма змагань включала попередні, полуфінальні та фрінальні заїзди.

У статті представлено фррагмент досліджень групи каноїстів (два спортсмени - чоловіки) - членів національної збірної команди України з веслування на байдарках і каное, МСМК. Спортсмени виступали в дисциплінах: чоловіки - каное двійка 1000 м (олімпійська) та 500 м каное четвірка.

Результати дослідження та дискусія. Підготовка спортсменів групи каное включала два макроцикли. Кожний з них закінчувався головним стартом. Протягом усього періоду підготовки вносилася корекція в тренувальний процес на основі оцінки їх фрункціонального стану методом ВКГ як найбільш им під час визначення гіпертрофрії міокарда порівняно з іншими електрофрізіологічними методами. За допомогою такого методу реєструють петлеподібні криві, які певним чином характеризують електричну активність різних ділянок серця.

Нижче наведено обгрунтування інформативності запропонованого методу для його використання та контролю функціонального стану спортсменів високої кваліфікації в різних мікроциклах річного циклу.

Векторкардіограма складається з трьох петель - P, QRS і T, які аналогічні зубцям звичайної електрокардіограми. Усі три петлі мають загальну нульову точку, в якій починається і закінчується петля. Велика зовнішня петля QRS відповідає процесу деполяризації шлуночків. Усередині розташована петля Т, що відображає процеси реполяризації. Найменша петля Р характеризує функціональний стан передсердь.

Багаторічними дослідженнями [2, 14, 16, 17] доведено перевагу методу ВКГ перед ЕКГ щодо більш ранньої діагностики початкових фрорм гіпертрофрії та дозволяє вирішити, за яким типом фрізіологічним або патологічним, відбувається іiі розвиток. ВКГ більш тонко реагує на фрізичне навантаження, що дозволяє краще виявити резервні можливості серця. Це дає відповідь про характер адаптації серця до навантаження. Стабільність

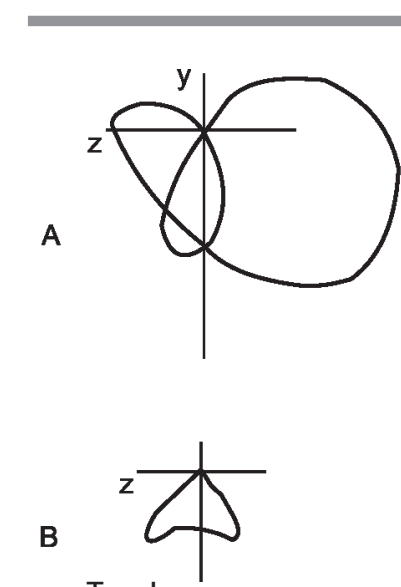

Тип I
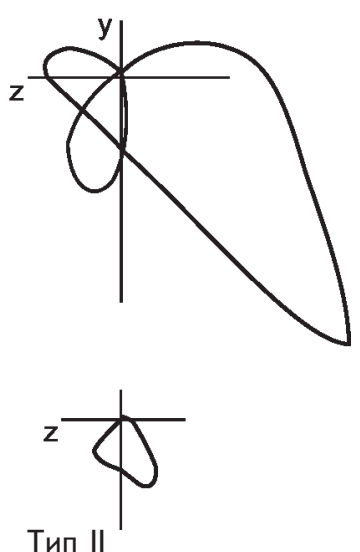

Тип II
Рисунок 1 - Адаптаційна перебудова об'ємного електричного поля шлуночків (А) і передсердь (В) у сагітальній площині залежно від спрямованості тренувального процесу у висококваліфікованих спортсменів (тип I - переважно з анаеробною спрямованістю; тип II - переважно з аеробною спрямованістю)

графріки ВКГ при динамічних спостереженнях розкриває перспективи використання ВКГ як інформативного методу дослідження поточного фрункціонального стану в різних структурних утвореннях річного циклу.

Передсердя відіграють важливу роль у збільшенні кровонаповнення шлуночків і підвищенні ефрективності їхньої роботи. Фізичні навантаження сприяють розвитку гіпертрофії міокарда топографрічно визначених відділів серця, а порівняння індивідуальних даних із модельними - оцінити стан резервних можливостей серця до фрізичних навантажень різної спрямованості. При цьому збільшення потенціалу векторів вільної стінки лівого шлуночка розцінюється як підвищення резервних можливостей серця переважно до роботи аеробного характеру, а передньої бокової стінки правого шлуночка і задньобазального відділу серця - до роботи швидкісно-силового характеру (рис. 1).

Метод ВКГ дозволяє визначити критерії оцінки високих та знижених резервних можливостей серця, що характеризують фрункціональні резерви серцево-судинної діяльності. Об'ємне електричне поле серця в річному тренувальному циклі зазнає певних змін: підвищується електрична активність міокарда в підготовчому та знижується в змагальному.

Зниження об'ємного електричного поля шлуночків у змагальному періоді тренування $€$ важливим чинником. Найбільше це виявляється в зміні просторової площі шлуночкової петлі. Зменшення площі петлі QRS у змагальному періоді після її збільшення в підготовчому періоді $€$ надійним критерієм оцінки високого рівня резервних можливостей серця у спортсменів, що розвивають витривалість. 


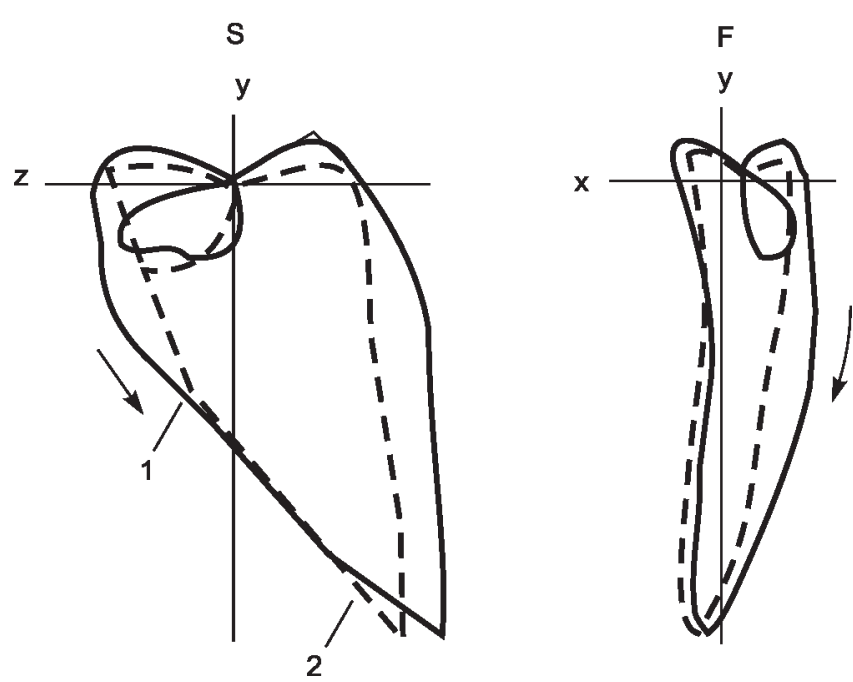

Рисунок 2 - Зменшення площі шлуночкової петлі в змагальному періоді тренування (2) порівняно з підготовчим (1) у ЗМС з веслування на байдарках і каное (S - сагітальна площина; F - фронтальна площина)

Інтенсивне тренування прискорює зміну об'ємного електричного поля шлуночків. Дослідження показали, що оптимальне зменшення просторової площі петлі QRS у змагальному періоді порівняно з підготовчим становить 20-30\% (рис. 2).

Менш сприятливе її зниження - на 30-50\%. Відсутність у висококваліфрікованих спортсменів із великим спортивним стажем зменшення просторової площі петлі QRS наприкінці змагального періоду, а тим більше ії значне збільшення порівняно з підготовчим періодом, свідчать про неекономний шлях функціонування ССС і знижені резервні можливості серця. Це може бути результатом неадекватності тренувальних навантажень, їхньої інтенсифрікації та невідповідності періоду тренування. У першому випадку зменшення площі петлі QRS ще не досягнуто, а в другому - вже пройдено.

Динамічні дослідження фрункціонального стану ССС спортсменів різного рівня підготовленості дозволили встановити критерії знижених морфофункціональних можливостей серця, які $€$ прогностично несприятливими для подальшого підвищення функціональних резервів і зростання спортивних результатів: фрізіологічні; передпатологічні; патологічні.

Критерії характеризуються різними змінами ВКГ та мають ряд ознак. Фізіологічні критерії в загальну групу об'єднує:

1) єдиний патогенез - переважання різного ступеня виразності тоногенної дилатації серцевого м'яза (перевищує оптимальний рівень) над її гіпертрофрією. Ознаки зниження резервних можливостей серця виникають у здорових спортсменів і
Спортивна медицина і фізична реабілітація, № 1, 2020

пов'язані з тривалим, часом надмірним, впливом великих фрізичних навантажень.

2) різке зменшення площі петлі QRS у річному циклі підготовки. При значному зменшенні об'ємного електричного поля шлуночків від підготовчого до змагального періоду підготовки на векторкардіограмі спостерігається вузька й укорочена шлуночкова петля з малою площею. Загальна площа шлуночкової петлі зменшена у змагальному періоді більше ніж на 30 \% відносно підготовчого періоду (рис. 3). Зазначені векторкардіографрічні зміни поєднуються зі зниженням спеціальної працездатності (саме швидкісних якостей), тоді як спроможність до роботи аеробного характеру зберігається. Цей стан минає, і до наступного тренувального періоду електрична активність шлуночків відновлюється.

Якщо в динаміці річного циклу, незважаючи на зміни характеру і спрямованості тренувального процесу, відповідно до періодів підготовки спостерігається майже незмінна графіка шлуночкової петлі, то визначається так звана застигла петля, де одна петля неначе вписується в іншу.

Наступна ознака, коли ВКГ шлуночків характеризується помірно вираженою гіпертрофрією міокарда переважно правого або лівого шлуночка і супроводжується підвищеною активацією передсердь, що свідчить про зниження скорочувальної фрункції міокарда шлуночків. Такі зміни зазвичай зустрічаються у спортсменів з великим спортивним стажем (рис. 4 ; I тип).

Стабілізація об'ємного електричного поля шлуночків у різні періоди річного тренувального
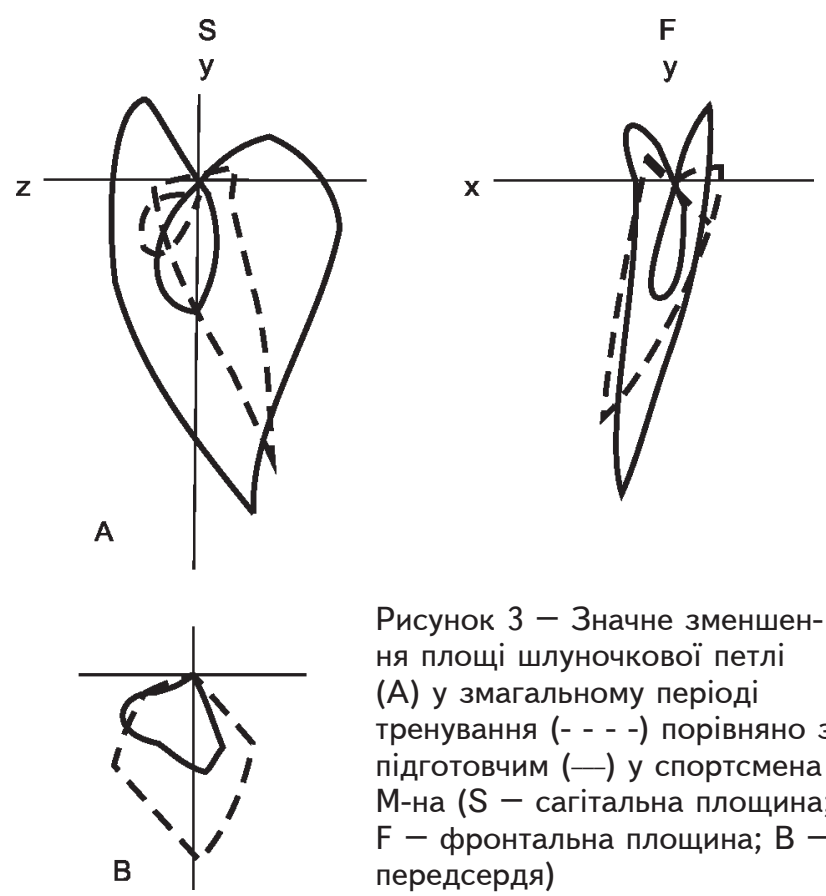

Рисунок 3 - Значне зменшення площі шлуночкової петлі (А) у змагальному періоді тренування (- - - -) порівняно з підготовчим (-) у спортсмена M-на (S - сагітальна площина; F - фронтальна площина; B передсердя) 

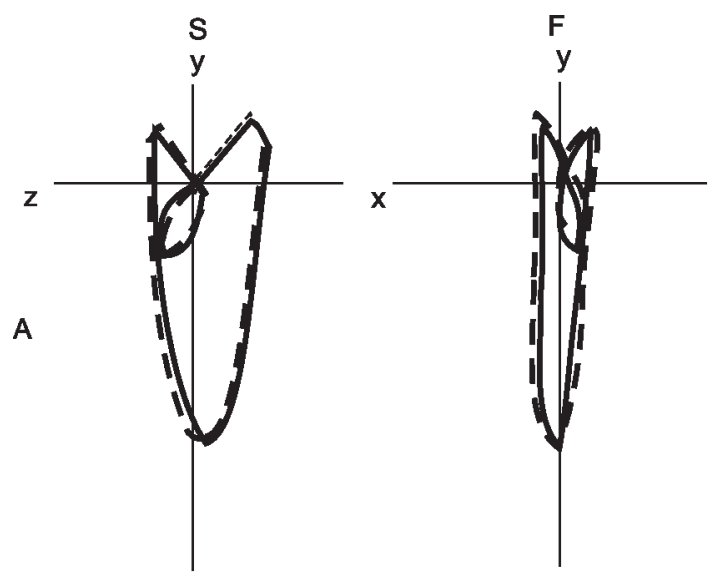

B

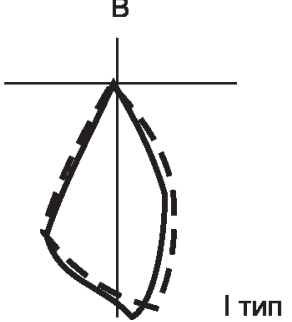

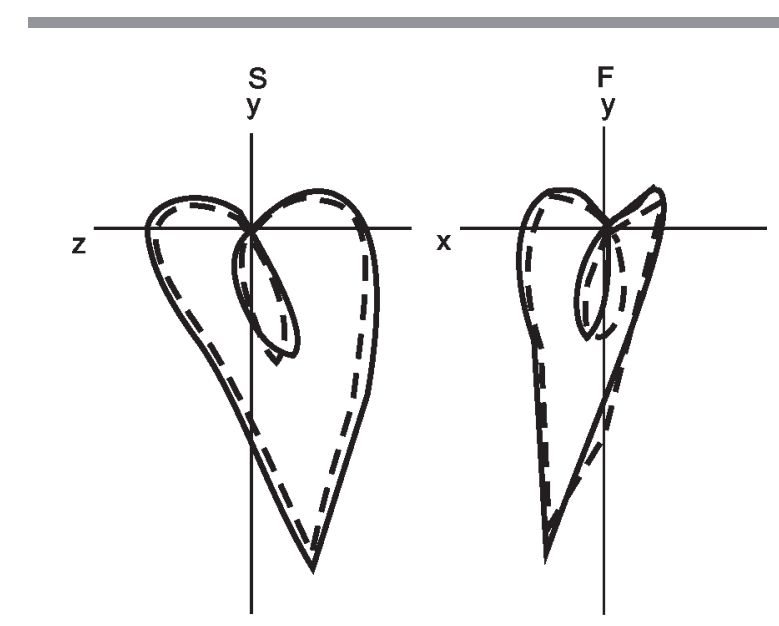

B

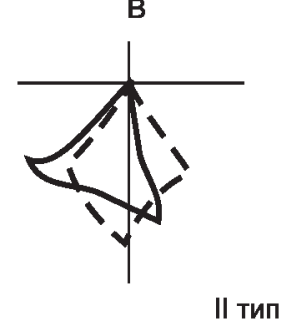

Рисунок 4 - Стабілізація об'ємного електричного поля шлуночків (А) у змагальному періоді тренування (-) порівняно з підготовчим (- - -) у висококваліфрікованих спортсменів (I тип - біатлон, вік 27 років, спортивний стаж - 15 років; II тип - академічне веслування, вік 19 років, спортивний стаж п'ять років; S - сагітальна площина; F - фронтальна площина; В - передсердя)

циклу іноді спостерігається й у молодих спортсменів. Однак вона не супроводжується підвищенням активізації передсердь і здебільшого пов'язана 3 невикористаними функціональними можливостями серця. Це $є$ підґрунтям подальшого збільшення тренувальних навантажень відповідно до плану підготовки та розширення резервних можливостей серця (рис. 4; II тип).

Наступна ознака пов'язана з поступовим зменшенням площі петлі QRS у процесі багаторічної підготовки. У спортсменів з великим спортивним

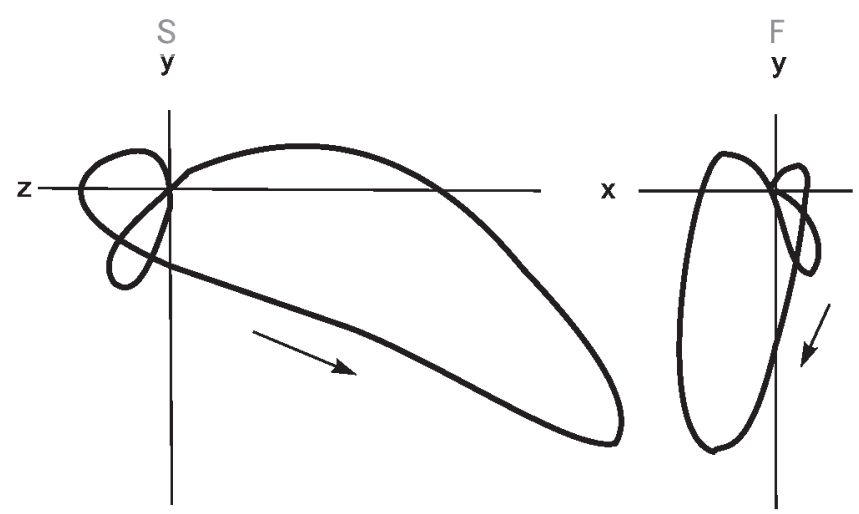

Рисунок 5 - Спотворена форма шлуночкової петлі в підготовчому періоді тренування у МС з плавання (S - сагітальна площина; F - фронтальна площина) стажем спостерігається поступове зменшення об'ємного електричного поля шлуночків, що найбільш чітко виявляється у підготовчому періоді тренування. Така ознака спостерігається часто разом із тенденцією до стабілізації графріки ВКГ шлуночків у річному циклі. Ці зміни $є$ наслідком превалювання тоногенної дилатації над гіпертрофрією міокарда і можуть слугувати передвісником стабілізації, а в подальшому призводити до зниження резервних можливостей серця. Це один із чинників зниження спортивної працездатності при збільшенні спортивного стажу і віку.

Передпатологічні зміни в стані електричної активності серця найчастіше виникають у результаті інтенсифікації та фоорсування підготовки спортсменів. Форма петлі QRS приймає вигляд «лежачої» петлі. Це відбувається за рахунок ії розширення і петля набуває фрорми еліпса. Така графріка ВКГ характеризує гіпертрофрію міокарда, переважно лівого або правого шлуночка (рис. 5).

Змінена графріка петлі QRS є одним 3 інфрормативних критеріїв хронічного перенавантаження міокарда шлуночків у спортсменів. Це призводить до швидкого розвитку гіпертрофії і дилатації. «Лежача» петля спостерігається у молодих перспективних спортсменів, у тренуванні яких від- 
ТАБЛИЦЯ 1 - Програма змагань досліджуваної групи на ліцензійному чемпіонаті світу 2019 року

\begin{tabular}{|l|c|l|c|}
\hline Дисципліна & $\begin{array}{c}\text { Кількість } \\
\text { днів } \\
\text { змагань }\end{array}$ & \multicolumn{1}{|c|}{ День змагань } & $\begin{array}{c}\text { Кількість } \\
\text { заїздів }\end{array}$ \\
\hline $\begin{array}{l}\text { С-2 } 1000 \text { м - } \\
\text { олімпійська } \\
\text { дистанція } \\
\text { (Ш-ло, В-к) }\end{array}$ & 3 & $\begin{array}{l}22.08-\text { попередній } \\
\text { заїзд } \\
23.08-\text { полуфінал } \\
24.08-\text { фінал }\end{array}$ & 3 \\
\hline $\begin{array}{l}\text { С-2 500 м } \\
\text { (Ш-ло, В-к) }\end{array}$ & 3 & $\begin{array}{l}21.08-\text { попередній } \\
\text { заїзд } \\
22.08-\text { полуфінал } \\
23.08-\text { фінал ( не } \\
\text { потрапили) }\end{array}$ & 2 \\
\hline $\begin{array}{l}\text { С-4 500 м } \\
\text { (Ш-ло, В-к, } \\
\text { Б-к, Т-к) }\end{array}$ & 2 & $\begin{array}{l}22.08-\text { попередній } \\
\text { заїзд } \\
25.08-\text { фінал }\end{array}$ & 2 \\
\hline
\end{tabular}

мічається період фрорсованої підготовки на фроні недостатньої загальної витривалості, а також за наявності хронічної інфрекції. Такі спортсмени характеризуються зниженими функціональними можливостями і нестабільними спортивними результатами. Іноді такі спортсмени можуть прогресувати і розвивати швидкісні якості, у них не відмічається значного прогресу в розвитку спеціальної витривалості.

Патологічні критерії не відрізняються від клінічних та їх виявляють у спортсменів з гострими або хронічними інфекціями, захворюваннями серцево-судинної системи.

Таким чином, кількісні модельні характеристики об'ємного електричного поля серця спортсменів високого класу становлять нормативну основу оцінки його функціонального стану, що відповідає періоду підготовки і спрямованості тренувального процесу, а розроблені критерії оцінки резервних можливостей серця з урахуванням віку і спортивного стажу можуть застосовуватися під час контролю та відбору спортсменів для участі у відповідальних змаганнях. За результатами досліджень $є$ можливість проведення корекції тренувального процесу, заходів відновлювальної терапії.

Такий підхід до застосування методу ВКГ дозволив ефективно спостерігати динаміку змін серця спортсменів високої кваліфікації збірної команди України з веслування на байдарках і каное протягом річного циклу.

Етап безпосередньої підготовки до головних змагань 2019 р. (третій рік олімпійського циклу) був орієнтований на збереження базових компонентів підготовленості, максимально доступний розвиток спеціальних компонентів і забезпечення повноцінного відновлення і досягнення найвищого рівня адаптації та готовності до стартів під час ліцензійного чемпіонату світу з веслування на бай-
Спортивна медицина і фізична реабілітація, № 1, 2020

дарках і каное. Змагальний мікроцикл містив п'ять днів (21-25 серпня 2019 р.) і для збірної команди України стояло завдання завоювати максимальну кількість ліцензій. Для групи каное (чоловіки) розігрувалися дві ліцензії.

В ході досліджень нами було закцетовано увагу на підготовку і виступ чоловічої групи каное (а саме каное двійки), яка виступала на олімпійських дистанціях відповідно до програми змагань (табл. 1).

Ліцензії в чоловічому каное з трьох дистанцій одна була олімпійська (С2 1000 м) (табл. 1). Спортсмени виступали всі п'ять днів 321 по 25 серпня 2019 р. (рис. 6).

Необхідно зазначити, що в чоловічому каное спортсмени стартували 7 разів за п'ять днів - 3 рази в попередніх заїздах, по два рази в полуфіналах та фрінальних заїздах (рис. 7). Ліцензія розігрувалася на дистанції 1000 м на четвертий день змагань, після виступу в п'яти заїздах. Протягом виступу на змаганнях зранку проводилися дослідження фрункціонального стану ССС методом ВКГ.

Простежуючи динаміку показників ВКГ протягом чотирьох обстежень у спортсмена В-ка (МСМК, спортивний стаж 9 років), звертає на себе увагу зменшення загальної площі шлуночкової петлі 22.08.2019 р. на 16,6 \% порівняно $з$ 21.08.2019 p.

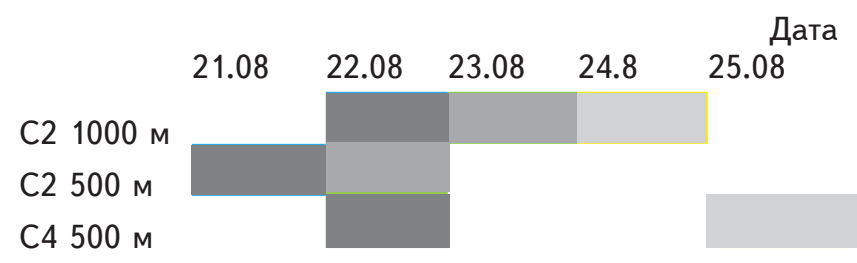

Рисунок 6 - Схема розподілу змагальних стартів у спортсменів-чоловіків досліджуваної групи каное на чемпіонаті світу 2019 р. ( $\square$ - попередній заїзд, $\square$ - полуфінал, $\square$ - фрінал)

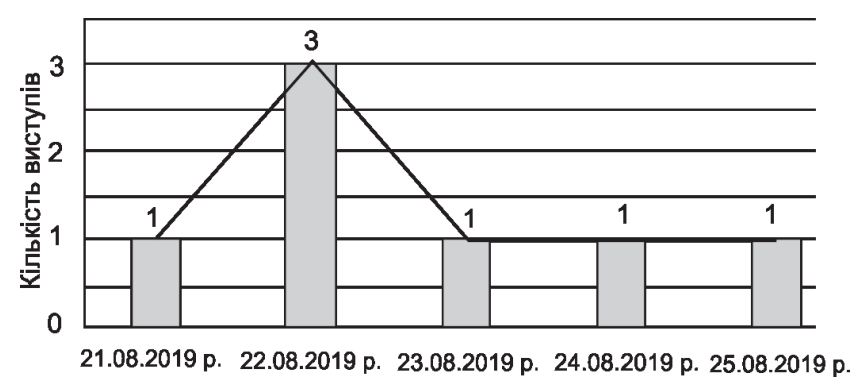

Рисунок 7 - Кількість виступів членів одного екіпажу каное двійки в різних дисциплінах чемпіонату світу 2019 р.:

стовпчик - спортсмен В-к, лінія - Ш-о 
Спортивна медицина і фізична реабілітація, № 1, 2020

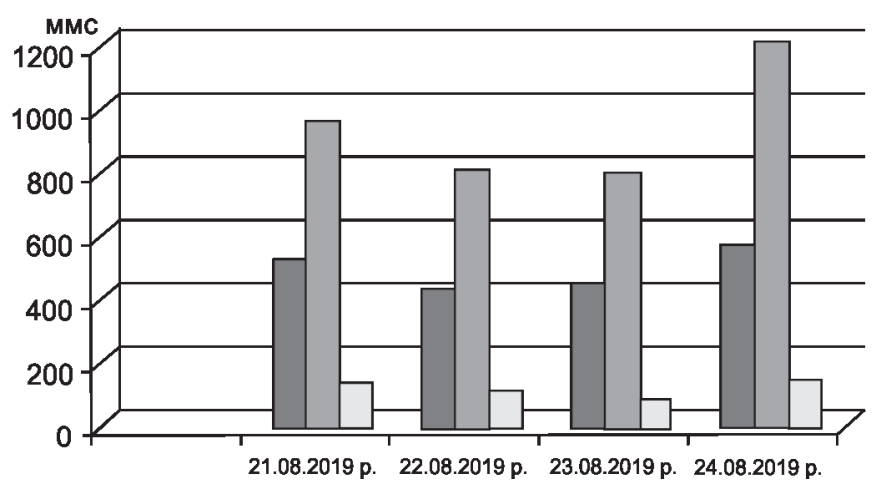

Рисунок 8 - Моніторинг просторової загальної площі петлі P ( $\square)$, петлі QRS ( $\square)$ і петлі T ( $\square$ ) у висококваліфікованого спортсмена В-ка (МСМК, спортивний стаж дев'ять років) на чемпіонаті світу 2019 р.

У цей же час спостерігалось зменшення напруженості в роботі серця за рахунок того, що загальна площа передсердь зменшилась на $18,56 \%$. Зниження електричної активності передсердь сприяло більш економічній роботі серця. Незважаючи на те що загальна площа петлі Т мала тенденцію до зниження на 17,91 \% рівень метаболічного забезпечення міокарда зберігався високим. Про це свідчить і коефріцієнт Г/Т, який відповідно дорівнював 1,38, та 1,39 ум. од. (рис. 8-11).

Зменшення загальної площі QRS відбувалось за рахунок площі трикутників як першої (П-Г), так і другої (Г-К) її половини. Так, площа моментного трикутника 10-20 мс зросла більше як в 2 рази, 30-40 мс - на 20,69 \%. Водночас зменшилась площа моментних трикутників 20-30 мс на 5,71 \%, 40-50, 50-60мс - відповідно на 26,75\% та $31,86 \%$ (див. рис. 10 ).

У подальшому (на третій день змагань) значних змін у стані об'ємного електричного поля шлуночків не відбулось. Кумулятивний ефект змагальних навантажень сприяв незначному підвищенню

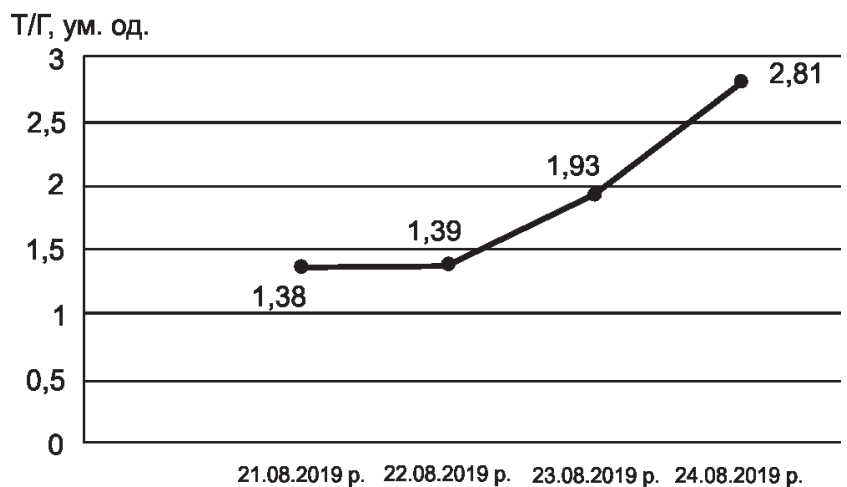

Рисунок 9 - Моніторинг коефріцієнта Г/Т у восококваліфікованного спортсмена В-ка (МСМК, спортивний стаж дев'ять років) на чемпіонаті світу 2019 р.

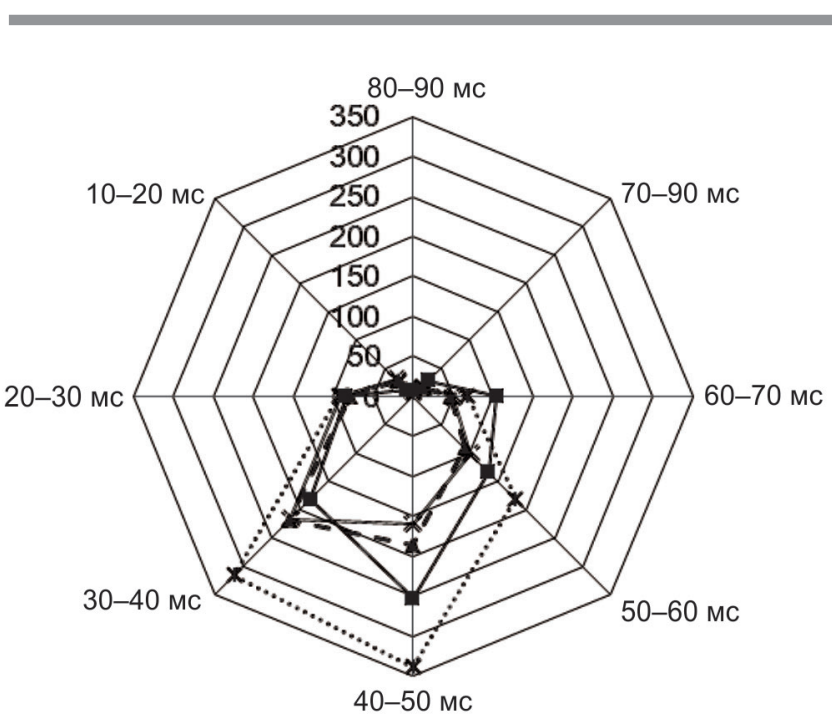

Рисунок 10 - Моніторинг площі моментних трикутників шлуночкової петлі у висококваліфрікованого спортсмена В-ка (МСМК, спортивний стаж дев'ять років) на чемпіонаті світу 2019 р.:

$\longrightarrow-\quad 21.06 .2019$ p.; - * - -22.08 .2019 p.;

$\because-23.08 .2019$ p.; $\cdots * \cdots-24.08 .2019$ p.

електричної активності передсердь та деякому зниженню загальної площі петлі Т (див. рис. 8). Загальна площа петлі Р збільшилась на 4,22 \%. При цьому у спортсмена зберігався достатній рівень метаболічного забезпечення міокарда (Г/Т дорівнював 1,93 ум. од.) ( рис. 9).

Отримані зрушення можна пояснити змагальними навантаженнями в попередні дні та розцінювати їх як повільне відновлення. Незважаючи на те що загальна площа шлуночкової петлі не зазнала значних змін, відмічається зменшення площі трикутника П-Г на 11,63 \% та підвищення площі трикутника Г-К на 17,63 \%.

Електрична активність підвищилась в області передньо-бокової стінки правого шлуночка та бокової стінки лівого шлуночка. Площа моментного

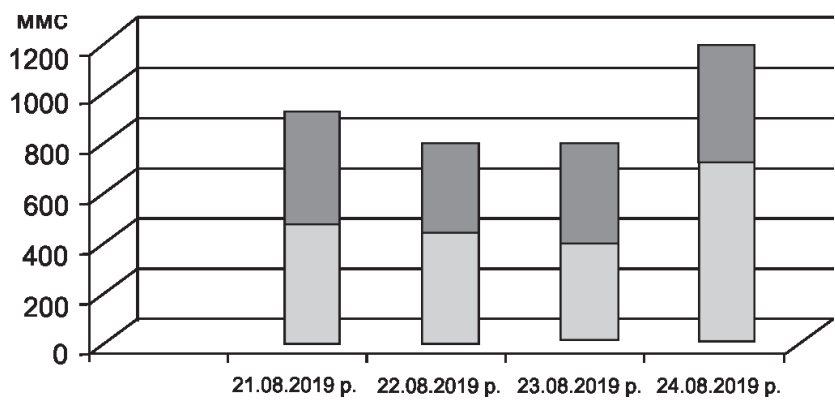

Рисунок 11 - Моніторінг площі першої ( $\square$ ) та другої ( $\square$ ) половини шлуночкової петлі (QRS) у висококваліфікованого спортсмена В-ка (МСМК, спортивний стаж дев'ять років) 


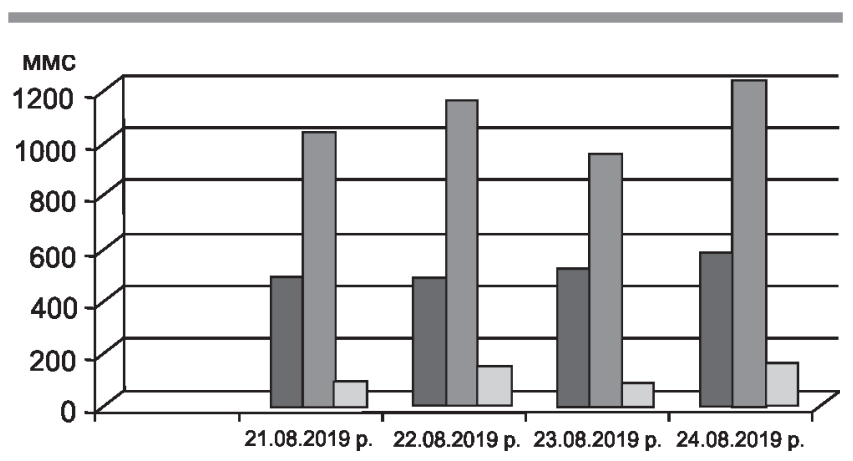

Рисунок 12 - Моніторинг просторової загальної площі петлі P ( $\square)$, петлі QRS ( $\square)$ і петлі T ( $\square)$ у висококваліфікованого спортсмена Ш-ло (ЗМС, спортивний стаж 15 років) на чемпіонаті світу 2019 р.

трикутника 20-30 мс зросла на $13,62 \%$ та 5060 мс на 11,46\%. В той же час в області вільної стінки лівого шлуночка площа моментного трикутника 40-50 мс зменшилась на 14,21\%. Відбулась переорієнтація електричної активності серця в різних його відділах. Ніяких порушень з боку діяльності серцевого м'яза не було виявлено.

На заключному обстеженні в день фріналу на олімпійській дистанції (24.08.2019р.) ми спостерігали підвищення загальної площі шлуночкової петлі на 52,4 \%. Зміни відбувались за рахунок підвищення електричного потенціалу майже всіх відділів серця і супроводжувалося підвищенням рівня метаболічного забезпечення міокарда, про що свідчить зростання загальної площі петлі Т більше ніж в два рази та електричної активності передсердь, загальна площа петлі Р зросла на 29,75 \% (див. рис. 8). Зростання загальної площі шлуночкової петлі (QRS) відбувалось за рахунок площі моментних трикутників 30-40, 50-60, 60-70 мс (відповідно на 45,56, 78,73, 36,02,7 та 66,7 \%), 40-50 мс більше ніж в два рази. Підвищення електрорушійної сили серця відбулось переважно в його правих відділах. Про це свідчить зростання площі трикутника П-Г з 396,6 ммс - 23.08.

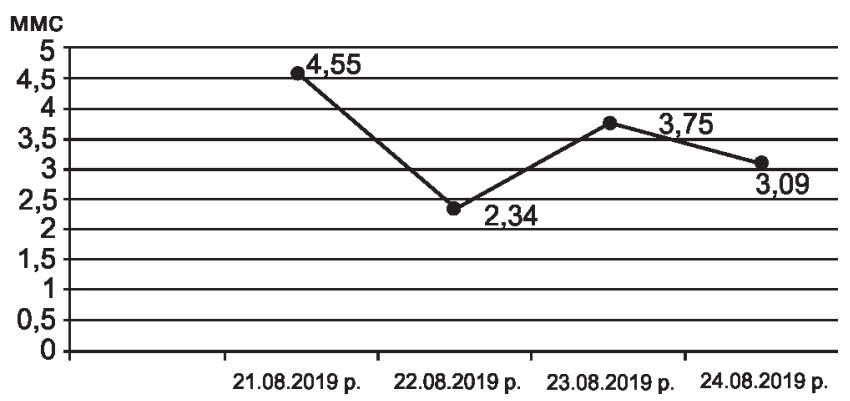

Рисунок 13 - Моніторинг коефіцієнта Г/Т у висококваліфрікованого спортсмена Ш-ло (ЗМС, спортивний стаж 15 років) на чемпіонаті світу 2019 р.
Спортивна медицина і фізична реабілітація, № 1, 2020

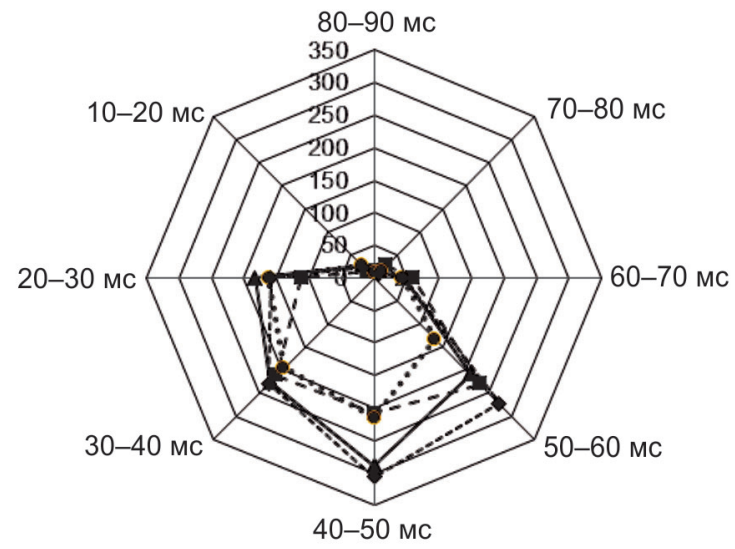

Рисунок 14 - Моніторинг площі моментних трикутників шлуночкової петлі у висококваліфікованного спортсмена Ш-ло (ЗМС, спортивний стаж 15 років) на чемпіонаті світу 2019 р.:

- - - - 21.08.2019 p.; $\longrightarrow$ - 22.08.2019 p.; •••. 23.08.2019 p.; - - 24.08.2019 p.

до 723,9 ммс 24.08.2019p. (рис. 11). Підвищення загальної площі петлі QRS (шлуночкової) та P (передсердь) свідчить про напружене функціювання та неекономічну роботу серця. Виникла необхідність відновлювальних заходів.

У спортсмена Ш-ло протягом всіх днів чемпіонату світу показники ВКГ передсердь та шлуночків мали зміни. Простежуючи їх динаміку протягом чотирьох обстежень, звертає на себе увагу збільшення загальної площі QRS 22,08 на 12,23 \% порівняно з попереднім обстеженням. У цей же час фрункція передсердь була в межах фрізіологічної норми. Підвищився рівень метаболічного забезпечення міокарда, про що свідчить зростання загальної площі петлі Т майже вдвічі. Коефіцієнт співвідношення процесів де- та реполяризації зменшився на $48,57 \%$ з 4,55 до 2,34 ум.од. (рис. 12-15).

Збільшення загальної площі шлуночкової петлі QRS відбувалось за рахунок моментних трикутників 20-30, 30-40, 40-50 мс відповідно

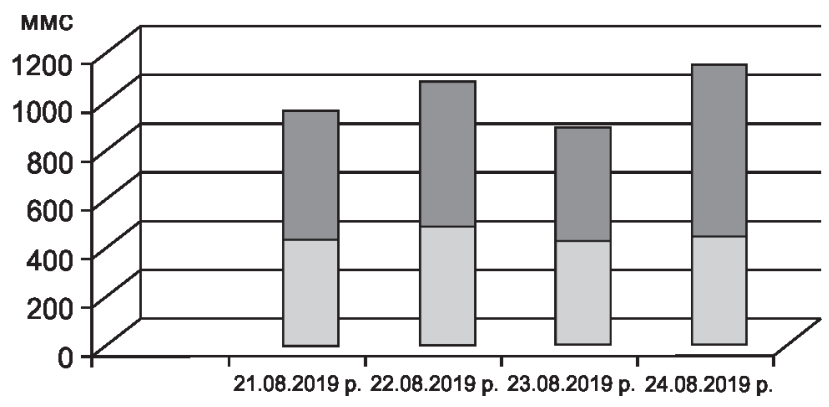

Рисунок 15 - Моніторінг площі першої ( $\square$ ) та другої ( $\square$ половини шлуночкової петлі (QRS) у висококваліфрікованого спортсмена Ш-ло (ЗМС, спортивний стаж 15 років) 
Спортивна медицина і фізична реабілітація, № 1, 2020

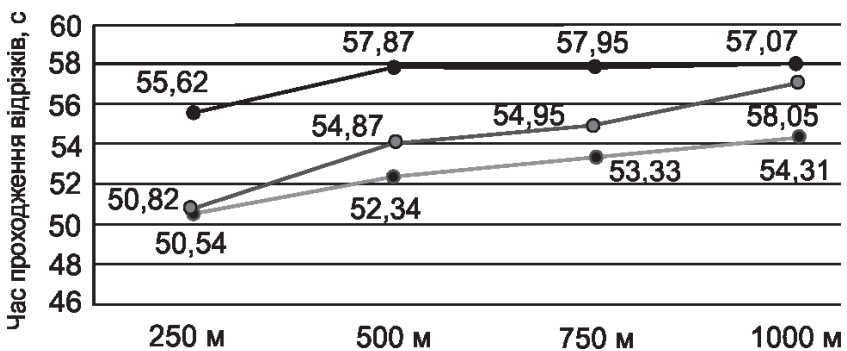

Рисунок 16 - Проходження дистанції 1000 м екіпажем С2 каное двійки на чемпіонаті світу 2019 р.:

попередній (-๑), полуфрінальний (-૦-) та фрінальний $(-\rightarrow)$ заїзди

на 63,53\%, 56,5 \%, 38,54 \%, площа трикутника 10-20 мс зросла в два рази. Тобто, електрична активність підвищилась в різних відділах шлуночків: бокової, передньої стінки правого шлуночка і вільної стінки лівого шлуночка. Підвищення електрорушійної сили серця відбулось в його правих та лівих відділах, про це свідчить також підвищення площі трикутників П-Г на 12,8 \% та Г-К на 13,52 \% (рис. 13).

У подальшому об'ємне електричне поле шлуночків поступово зменшується. Кумулятивний ефект змагальних навантажень двох днів сприяв розкриттю та реалізації функціональних можливостей серця до виконання роботи анаеробного та аеробного характеру. При цьому у спортсмена зберігався достатній рівень метаболічного забезпечення міокарда. Електрична активність передсердь зросла на 7,91\%, їх можна розцінювати як неповне відновлення. Зменшення загальної площі шлуночкової петлі на 18,06\% відбувалось за рахунок зниження електричної активності як правих, так і лівих відділів серця.

Це підтверджується зниженням площі трикутників П-Г на 11,86 \%, Г-К - на 23,78 \% та моментних трикутників 20-30, 30-40, 40-50, 50-60 мс відповідно на 11,45 \%, 13,56 \%, 25,61\%, 36,41\% (рис. 13). При обстеженні зранку в день фрінальних змагань на олімпійській дистанції (24.08.2019р.) відбулось підвищення загальної площі шлуночкової петлі на 28,91 \% та електричної активності на $10,71 \%$.

Рівень метаболічного забезпечення міокарда мав тенденцію до зростання. Загальна площа петлі Т зросла майже в три рази. Збільшення загальної площі QRS відбувалось за рахунок моментних трикутників 30-40, 40-50, 60-70 мс відповідно на 16,91, 42,75, 6,79 \%, площа 50-60 мс підвищилась у два рази, тобто бокової та передньої стінки правого шлуночка, задньої та вільної стінки лівого шлуночка.
Зростання електрорушійної сили серця відбулось переважно в лівих відділах серця. Про це свідчить підвищення площі трикутників П-Г тільки на 4,50 \%, а Г-К на 54,18\% (див. рис. 12-15).

Нами відзначено, що в одному екіпажі - каное двійці спостерігається індивідуальна адаптація серцевого м'яза на змагальні навантаження протягом п'яти днів. У спортсмена В-ка вже на другий день змагань спостерігалась тенденція до реалізації можливостей серцевого м'яза і на третій день максимальна реалізація, реагування на змагальні навантаження правих відділів серцевого м'яза та накопичення на четвертий день змагань (після проходження п'яти стартів та виходу у фрінал на олімпійській дистанції С2 1000 м) втомлення та ознаки недовідновлення. Тоді як у другого спортсмена в екіпажі Ш-ло реалізацію можливостей серцевого м'яза відзначено на третій день змагань, на змагальні навантаження переважно реагували ліві відділи серцевого м'яза. Про це свідчить і виступ спортсменів на третій день змагань у полуфріналі та потрапляння до фріналу на олімпійській дистанції 1000 м (рис. 16).

Проходження олімпійської дистанції 1000 м від попереднього до фрінального заїздів свідчить про максимальну реалізацію можливостей саме в полуфрінальному заїзді, де екіпаж продемонстрував проходження дистанції зі стабільним утриманням швидкості, кращий час на відрізках. Необхідно зазначити, шо у фріналі спортсмени продемонстрували стабільне проходження всієї дистанції, що дозволило екіпажу отримати ліцензію.

Висновки. Проведені дослідження та багаторічний досвід свідчать про високу інформативність методу ВКГ. Даний метод дозволяє чітко визначити пристосування серцевого м'яза до тренувальних та змагальних навантажень протягом спортивного сезону, в різних структурних утвореннях, визначити ознаки фрормування адаптації серця, метаболічні процеси.

Незважаючи на загальні закономірності пристосувальних реакцій серця та ремоделювання серцевого м'яза до змагальних навантажень результати досліджень свідчать про індивідуальні особливості адаптації серця спортсменів у період головних міжнародних змагань спортивного сезону.

Адаптація серцевого м'яза під впливом змагальних навантажень у змагальному періоді, спрямована на розкриття та реалізацію функціональних можливостей, мала суто індивідуальні прояви.

Прояви індивідуального ремоделювання серцевого м'яза пов'язані з віком, кваліфікацією, спортивним стажем та ін. 
Застосування методу ВКГ дозвили здійснювати постійний моніторинг навантажень, вносити корекцію в тренувальний процес та підвести

\section{Література}

1. Белоцерковский ЗБ, Любина БГ, Койдинова ГА. Электрическая активность сердца и физическая работоспособность у спортсменов [Heart electrical activity and physical work capacity of athletes]. Теория и практика фозической культуры. 2009; 1: 12-19.

2. Шинкарук ОА, Лисенко ОМ, Тайболіна ЛА, Чередниченко ОО. Веслування на байдарках і каное: підсумки і аналіз виступу на XXVII Олімпійських іграх 2000 року [Kayaking and canoeing: results and analysis of performance at the XXVII Olympic Games in 2000] метод. рекоменд. - Київ, 2000. - 61 с.

3. Граевская НД. Актуальные вопросы спортивной медицины [Current issues of sports medicine]. Лечебная физкультура и спортивная медицина. 2013; 7(115): 60-3.

4. Граевская НД, Гончарова ГА. Тренированность и спортивная формма с позиции медицины [Training status and competition form from the standpoint of medicine]. Современные технологии в реабилитации и спортивной медицине: матер. V Росс. науч. форума. Москва, 2005. 2830.., 2005;

5. Дембо АГ, Дембо АГ, Земцовский ЭВ. Спортивная кардиология: руководство для врачей [Sports cardiology: guide for physicians]. Москва: Медицина; 1989. 464 c.

6. Дрюков В, Павленко Ю, Павлик А. Индивидуализация подготовки спортсменов высокой квалифрикации по результатам проведения физиологического обследования в процессе этапного комплексного контроля [Individual preparation of top level athletes according to the results of physiological examination carried out during complex stage control]. Наука в олимпийском спорте. 2004; 1: 130-6.

7. Иванова ТС, Захарьева НН. Специфика показателей сердечного ритма легкоатлетов с различной спортивной результативностью [Specificity of cardiac rhythm indices in track and field athletes of different skill levels]. Теория и практика физической культуры и спорта. 2013; 2: 22-6.

8. Исаев АП, Личагина СА, Гаттаров РУ, и др. Адаптация человека к спортивной деятельности [Human adaptation to athletic activity]. Ростовна-Дону: Изд-во РГПУ; 2004.236 с.

9. Исаев АП. Механизмыдолговременной адаптации и дисрегуляции фуннкций спортсменов к нагрузкам олимпийского цикла подготовки [Mechanisms of long-term function adaptation and dysregulation in athletes to the loads of the Olympic training cycle]. Авторефрерат. Челябинск; 1993. 54 c.

10. Карташова ЛА, Корнякова ВВ, Смитиенко ОЛ. Маркеры дизадаптации сердечно-сосудистой системы у спортсменов циклических и ациклических видов спорта по данным эхокардиографии [Markers of cardiovascular system deadaptation in athletes of cyclic and acyclic sports events according to echocardiography data]. Вестник ТюмГУ. 2008; 3: 39-45.

11. Макарова ГА. Спортивная медицина [Sports medicine]. Учебник. Москва: Сов.спорт; 2003. 480 с

12. Марушко ЮВ, Гищак ТВ, Козловский ВА. Состояние сердечнососудистой системы у спортсменов («спортивное сердце») [State of cardiovascular system in athletes ("athlete's heart")]. Спортивна медицина. 2008; 2: 21-42.

13. Матвеева, АМ, Попова МА. Оценка функциональной адаптации спортсменов и прогнозирование спортивных результатов [Assessment of athlete functional adaptation and sports result forecasting]. Физиология и здоровье человека: сб. науч. трудов I съезда физиологов СНГ. Сочи, Дагомыс; 2005. Т.2. С. 290

14. Шинкарук ОА, Лисенко ОМ, Гуніна ЛМ, Карленко ВП та ін.; під заг. ред. ОА. Шинкарук. Медико-біологічне забезпечення підготовки спортсменів збірних команд України з олімпійських видів спорту [Medicobiological support of national teams of Ukraine in the Olympic sports events].: навч.-метод. посіб. - Киев: Олімп. л-ра; 2009. 147 с.

15. Меерсон $Ф 3$, Пшенникова МГ. Адаптация к стрессорным ситуациям и физическим нагрузкам [Adaptation to stress situations and physical loads]. Москва: Медицина; 1988. 256 с.; спортсменів до реалізації фрункціональних можливостей серцевого м'яза в дні, на які припадали полуфінальні та фрінальні заїзди.

16. Методические рекомендации по оценке морфоофункционального состояния сердца у спортсменов высокой квалификации с использованием метода векторкардиографии [Methodical recommendations on evaluating heart morphofunctional state in elite athletes by means of vector cardiography method]. [МИ. Слободянюк, ЛА. Тайболина и др.]. Киев, 1987. $53 \mathrm{c}$.

17. Лысенко Е, Шинкарук О, Самуйленко В. и др. Особенности функциональных возможностей гребцов на байдарках и каноэ высокой квалификации [Peculiarities of functional capacities of highly skilled kayakers and canoeists]. Наука в олимпийском сnорте. 2004; 02: 65-71.

18. Фомин НА. Адаптация: общебиологические и психофризиологические основы [Adaptation: general biological and psychophysiological bases]. Москва: Изд-во «Теория и практика физической культуры»; 2003. $383 \mathrm{c}$.

19. Хрущев СВ. Спортивное сердце [Athlete's health]. Физкультура в профилактике, лечении и реабилитации. 2008; 2 (25): 55-64.

20. Шинкарук О. Динаміка показників підготовленості веслувальників в процесі багаторічного тренування. Фізична культура, сnорт та здоров'я нації: зб. наук. праць / гол. ред. ВМ. Костюкевич. - Випуск 5 - Вінниця, 2018: 316-23

21. Шинкарук ОА, Лысенко Е, Тайболина Л. Особенности подготовки и научно-методическое обеспечение этапа непосредственной подготовки в гребле на байдарках и каноэ к Играм XXIX Олимпиады [Preparation peculiarities and scientific and methodical support of the stage of direct preparation of kayakers and canoeists for XXIX Olympic Games]. Наука в олимпийском cnopme. 2009; 1: 134-48.

22. Шинкарук ОА. Інструментальні методи діагностики в системі комплексного контролю організму спортсменів високої кваліфікації [Instrumental diagnostic methods in the system of complex control for the body of top level athletes]. Здоров'я, фізичне виховання і спорт: перспективи та кращі практики : матеріали Міжнарод. наук.-практ. конф.; 15 трав. 2018 р.; ВМ. Савченко, Київ: ун-т імені Бориса Грінченка; 2018. С.178-81.

23. Шинкарук О. Узагальнення досвіду організації відбору в олімпійському спорті [Generalization of experience of selection organization in the Olympic sport]. Теорія і методика фізичного виховання і спорту. 2001; 2-3: 35-9.

24. Шинкарук ОА. Обгрунтування використання фізіологічних показників як критеріїв відбору спортсменів у циклічних видах спорту [Substantiating the usage of physiological indices as the criteria of athlete selection in cyclic sports events]. Актуальні проблеми фізичної культури і спорту 3б. наук. пр. Київ; 2004; 3: 52-5.

25. Шинкарук О. Особливості організації відбору спортсменів у циклічних видах спорту. Теорія і методика фрізичного виховання і спорту. 2002; 01: 34-42.

26. Яковенко О, Шинкарук О. Управління функціональним станом організму спортсменів, що спеціалізуються у веслуванні академічному, з використанням сучасних технологій [Managing functional state of rowers with application of modern technologies]. Матеріали II Всеукраїнської електронної конференції з міжнародною участю «Інноваційні та інфоормаційн технології у фізичній культурі, спорті, фізичній тераnії та ерготераnії», 18 квітня 2019 р., Київ: НУФВСУ; 2019. С. 71-2.

27. Kostiukevych V, Lazarenko N, Shchepotina N, Poseletska K, Stasiuk V, Shynkaruk O, Borysova O, Denysova L, Potop V, Vozniuk T, Dmytrenko S, Kulchytsk A I, Konnova M, lakovenko O. Programming of the training process of qualified football players in the competitive period of the macrocycle. Journal of Physical Education and Sport. 2019; 19 (6), Art 329: 219-299.

28. Kostiukevych V, Shynkaruk O, Kulchytska I, Borysova O, Vozniuk T, Yakovliv V, Denysova L, Konnova M, Khurtenko O, Perepelytsia O, Polishchuk $V$, Shevchyk $L$. Training process construction of the qualified volleybal women players in the preparatory period of two-cycle system of the annual 
training on the basis of model training tasks// Journal of Physical Education and Sport. 2019; 19 (2), Art 63: 427-35.

29. Mishchenko V, Mishchenko V, Suchanowski O, Shynkaruk O, Lysenko O, et al. Individualities of Cardiorespiratory Responsiveness to Shifts in Respiratory Homeostasis and Physical Exercise in Homogeneous Groups of High Performance athletes. Baltic Journal of Health and Physical Activity. 2010; 1: 13-29.

30. Shynkaruk OA. Features of adaptation the organism of the high-class sportswoman in rowing on kayaks at the stage of direct preparation for the main competitions of the year cycle / O. Shynkaruk, O. Lysenko, L. Taibolyna // Book of abstracts 5 intern. scient. congress «Sport, stress, adaptation». 2010: P. 52.

shi-oksana@ukr.net
31. Tukaiev S, Dolgova O, Van Den Tol AJM, Ruzhenkova A, Lysenko $O$, Fedorchuk S, Ivaskevych D, Shynkaruk O, Denysova L, Usychenko V, lakovenko O, Byshevets N, Serhiyenko K, Voronova V. Individual psychological determinants of stress resistance in rock climbers. Journal of Physical Education and Sport. 2020; 20 (1), Art 69: 469-76.

32. Voronova V, Khmelnitska I, Shynkaruk O, Borysova O, Kostyukevich V, Zhovnych $\mathrm{Oa}$. Gender peculiarities of personality's qualities development in football. Journal of Physical Education and Sport. 2020; 20 (1), Art 71 484-9.

33. Wilmore, J.H. Physiology of Sport and Exercise / J.H. Wilmore, D.L. Costill, W.L. Kenney. Champaign, IL: Human Kinetics, 2008: P. 574.

Надійшла 22.01.2020 